\title{
THE INTEGRATED EFFECT OF MINERAL AND ORGANIC NITROGEN FERTILIZATION ON WHEAT UNDER SUSTAINABLE AGRICULTURAL SYSTEMS: 1- YIELD AND NITROGEN FERTILIZER USE EFFICIENCY. El-Hadidi, E.M. ; A. A. Mosa and Rania. M. El-Samet Soils Dept., Fac. of Agriculture, Mansoura Univ., Egypt
}

\begin{abstract}
Two pot experiments were carried out in the experimental farm of Faculty of Agriculture- Mansoura University to investigate the best integrated mineral and organic fertilization system which will reflect on increasing grain and straw yield as well as nitrogen fertilizer use efficiency by wheat (Triticum aestivum, L).

The used experimental design was split split plot design with three replicates, the main treatments were mineral nitrogen form which were: urea $46 \% \mathrm{~N}$, ammonium nitrate (AN) $33.5 \% \mathrm{~N}$, urea formaldehyde coated urea (UFCU) $37.2 \% \mathrm{~N}$ and urea coated rock phosphate (UCRPh) $37.2 \% \mathrm{~N}$.

Subplots represent mineral nitrogen fertilization level as 50 and $100 \mathrm{KgNFed}^{-1}$, and organic amendments forms were allocated in sub-sub plots.

Results showed that slow release mineral nitrogen sources (UFCU and UCRPh) were better than soluble nitrogen sources (Urea and AN) in increasing grain and straw yield as well as nitrogen use efficiency, also increasing mineral nitrogen level from 50 to $100 \mathrm{KgNFed}^{-1}$ led to an increasing in grain and straw yields in both seasons.

On the other hand, organic amendments forms resulted in increasing grain and straw yields, in addition to mineral nitrogen use efficiency, and chicken manure was better than farmyard manure, that's because of its high content of available nitrogen content.

Finally, it could be concluded that application urea coated rock phosphate at $100 \mathrm{KgNFed}^{-1}$ and $10 \mathrm{~m}^{3} /$ fed chicken manure was the best integrated treatment in increasing wheat grain and straw yields, as well as nitrogen use efficiency, and this will help to solve the gap between wheat supplies and demands in a friendly way with the environment.

Keywords: Wheat, mineral nitrogen sources, levels, nitrogen use efficiency, organic amendments

\section{INTRODUTION}

Sustainable agriculture must produce enough food to satisfy changing human needs while conserving natural resources, maintaining the quality of the environment and ultimately leading to community and gender equity.

Chemical nitrogen fertilizer has been held as a major hazard for environmental pollution, especially the nitrate enrichment of groundwater which is harming water ecosystem and increases aquatic weeds.

Unfortunately, there are many regions in Egypt usually use ground water as only source of drinking water which causes a lot of vital hazards to human health, and unfortunately too infants during the first three to four months of life is the major concern, in which nitrate can oxidizes the iron of hemoglobin in blood to form methemoglobin, so called methemoglobinemia, or blue baby syndrome (Sohar and Domoki, 1980).
\end{abstract}


On the other hand, the emission of nitrogenous gases from fertilizers volatilization and also from fertilizers plants is one of the causes of "Global Warming" which led to shift the earth climate, and also it is one of the factors which resulted in depletion of ozone layer.

In the last few decades, intensive crop cultivation requires the use of chemical nitrogen fertilizers, which became very little offered and very expensive, therefore, the current trend is to explore the possibility of supplementing chemical nitrogen fertilizers with other organic forms to match with crop nutrition needs and improve soil physical chemical and biological properties (FAO, 2005).

Another scheme of managing nitrate leaching and increasing nitrogen fertilizers use efficiency is using slow release nitrogen fertilizers which is leading to the development of sustainable agriculture (Elizabeth 2000)

The chemical and nutritional benefits of organic matter are related to the cycling of plant nutrients and the ability of the soil to supply nutrients for plant growth through microorganism's activation which are responsible for the mineralization and immobilization of $\mathrm{N}, \mathrm{P}$ and $\mathrm{S}$ through the decomposition of organic matter, as well as the influx of potassium from organic matter to enhance soil fertility (Duxbury and Doran, 1989).

The main goal of this research is to evaluate the best integrated fertilization system which increase wheat grain yield, as well as nitrogen use efficiency which will reflect on protecting the environment from pollution hazards.

\section{MATERIALS AND METHODS}

Two pot experiments were carried out in the experimental farm of Mansoura University during seasons of 2005 / 2006 and 2006 / 2007 to investigate the best integrated nitrogen fertilization treatment on wheat (Triticum aestivum, L) in the Egyptian alluvial soil.

\section{Soil analysis}

Surface soil samples $(0-30 \mathrm{~cm})$ were collected from the experimental farm; the collected samples were air-dried, crushed, and passed through a 2 $\mathrm{mm}$ sieve and preserved for analysis.

Some physical and chemical characteristics of the experimental soil are listed in Table (1). were used.

To judge soil characteristics perfectly the followed ideal methods

Particale size distribution for soil was carried out using the pipette method as described by Dewis and Fertias (1970), saturation percentage and field capacity of the soil were determined using the methods described by Richards (1954) and bulk density was determined by using paraffin wax method described by Dewis and Fertias (1970).

Soil organic matter content was determined by using Walkley \& Black method described by Hesse (1971), total carbonate was estimated gasometrically using Collins Calcimeter and calculated as calcium carbonate according to Dewis and Fertias (1970) and soil reaction $(\mathrm{pH})$ was measured 
in saturated soil paste using combined electrode $\mathrm{pH}$ meter as mentioned by Richards (1954).

Total Soluble salts were determined by measuring the electrical conductivity in the extraction of saturated soil paste in $\mathrm{dS} / \mathrm{m}$ as explained by Jackson (1967) and the amounts of water soluble cations (Ca++, $\mathrm{Mg}++, \mathrm{Na}+$ and $\mathrm{K}+)$ \& anions $(\mathrm{CO} 3=, \mathrm{HCO} 3-, \mathrm{Cl}-$ and $\mathrm{SO} 4=)$ were determined in the extract of saturated soil paste by the methods described by Hesse (1971).

Available nitrogen in the soil was extracted using $2.0 \mathrm{M} \mathrm{KCl}$ and determined by using macro-Kjeldahl according to Hesse (1971), available phosphorus in the soil was extracted with $\mathrm{NaHCO} 30.5 \mathrm{M}$ at $\mathrm{pH} 8.5$ and determined coloromitrically after treating it with ammonium molybedate and stannous chloride at a wavelength $660 \mathrm{~nm}$, according to Jackson (1967). Available potassium was determined by extracting soil with $1.0 \mathrm{~N}$ ammonium acetate at pH 7.0 as described by Hesse (1971) using flame photometer.

Table (1): Some physical and chemical analysis of the experimental soil

\begin{tabular}{|c|c|c|}
\hline Soil properties & & Values \\
\hline & physical pro & \\
\hline & Sand & $22.30 \%$ \\
\hline Particle size & Silt & $26.50 \%$ \\
\hline distribution & Clay & $51.20 \%$ \\
\hline & Soil texture & Clayey \\
\hline Hygroscopic water \% & & $8.68 \%$ \\
\hline Saturation percentage & & $72 \%$ \\
\hline Field capacity\% & & $36 \%$ \\
\hline Organic matter \% & & $1.96 \%$ \\
\hline Bulk density, $\mathrm{g} \mathrm{cm}^{-3}$ & & 1.33 \\
\hline Chemical properties & & \\
\hline Calcium carbonate, \% & & 3.85 \\
\hline $\mathrm{pH}$ (Soil paste) & & 7.6 \\
\hline Ec, $d S / m$ & & 1.78 \\
\hline & $\mathrm{Ca}^{++}$ & 6.48 \\
\hline Soluble cations & $\mathrm{Mg}^{++}$ & 3.13 \\
\hline$\left(m^{\prime} q L^{-1}\right)$ & $\mathrm{Na}^{+}$ & 5.92 \\
\hline & $\mathrm{K}^{+}$ & 0.28 \\
\hline & $\mathrm{CO}_{3}^{--}$ & 0 \\
\hline Soluble anions & $\mathrm{HCO}_{3}^{-}$ & 5.23 \\
\hline$\left(\operatorname{meq~L}^{-1}\right)$ & $\mathrm{Cl}^{-}$ & 6.74 \\
\hline & $\mathrm{SO}_{4}^{--}$ & 3.84 \\
\hline & Nitrogen & 37.35 \\
\hline Available nutrients & Phosphorus & 11.21 \\
\hline & Potassium & 321 \\
\hline
\end{tabular}

\section{Organic amendments analysis}

To analyze organic amendments, samples were taken from each type, and dried at $70^{\circ}$, finally it grounded using stainless steel equipments. $0.2 \mathrm{~g}$ of each sample was digested using $5 \mathrm{~cm}^{3}$ from the mixture of sulfuric $\left(\mathrm{H}_{2} \mathrm{SO}_{4}\right)$ and perchloric $\left(\mathrm{HCLO}_{4}\right)$ acids $(1: 1)$ as described by Peterburgski (1968). 
$\mathrm{pH}$ was determined in 1:5 water extract and measured using combined electrode $\mathrm{pH}$ meter as mentioned by Richards (1954).

Electrical conductivity was determined in $1: 10$ water extract in $\mathrm{dS} / \mathrm{m}$ as explained by Jackson (1967)

Organic matter content was determined using Walkley \& Black method described by Hesse (1971).

Total nitrogen was determined by micro-Kjeldahl method as explained by Hesse (1971), Phosphorus was determined colorimetrically at wavelength $680 \mathrm{~nm}$ using spectrophotometer (Spekol) as described by Jackson (1967), Potassium was determined by using Gallen Kamp flame photometer as mentioned by Jackson (1967).

Some chemical properties of organic amendments are shown in Table (2)

Table (2) Some chemical properties of organic amendments.

\begin{tabular}{|l|c|c|}
\hline Chemical properties & Farmyard manure & Chicken manure \\
\hline $\mathrm{P}^{\mathrm{H}^{*}}$ & 8.83 & 7.73 \\
\hline EC & 1.55 & 1.5 \\
\hline Total carbon Percentage & 12.38 & 28.44 \\
\hline $\mathrm{C}: \mathrm{N}$ ratio & 0.74 & 2.36 \\
\hline Total phosphorus percentage & 1.36 & 0.37 \\
\hline Total potassium percentage & 2.40 & 1.57 \\
\hline Organic matter percentage & $27: 12$ & 52.10 \\
\hline
\end{tabular}

* $\mathrm{pH}$ was determined in 1:5 water extract

${ }^{* \star}$ Ec was determined in 1:10 water extract

\section{The experiment's treatments}

The used experimental design was split-split plot design in three replicates. The main treatments were mineral nitrogen fertilization forms which wereurea $(46 \% \mathrm{~N})$, ammonium nitrate $(33.5 \% \mathrm{~N})$, urea formaldehyde coated urea (UFCU $37.2 \% \mathrm{~N}$ ) and Urea coated rock phosphate (UCRPh $37.2 \% \mathrm{~N})$.

Sup-plots were nitrogen fertilization levels as 50 and $100 \mathrm{Kg} \mathrm{N} \mathrm{Fed}^{-1}$, while sub-sub treatments were organic amendments addition which were: without organic form, farmyard manure and chicken manure.

Pots were sown with wheat seeds (Triticum aestivum, L) Sakha93 in $15^{\text {th }}$ November in both seasons and harvested in $11^{\text {th }}$ and $12^{\text {th }}$ April in the first and second seasons, respectively.

Farmyard manure and chicken manure were added at rates 20 and $10 \mathrm{~m}^{3} \mathrm{Fed}^{-1}$, respectively, before cultivation.

Soil was fertilized with superphosphate $(7 \%$ P) added before cultivation, while nitrogen fertilizer was added in two equal doses, the first one was after 30 days from sowing and the second dose was added during booting stage (60 days from sowing).

Pots were fertilized with potassium as potassium sulfate $(40 \% \mathrm{~K})$ before planting .

\section{Nitrogen use efficiency}

Nitrogen use efficiency was calculated as grain yield $(\mathrm{Kg})$ produced due to adding units of nitrogenous fertilizer (Fiez et al., 1994). 


\section{N.U.E = \\ Grain yield (Kg) \\ Units of nitrogen fertilizer added}

\section{Statistical analysis}

The experimental design was complete randomized block design with three replicates. All the plants received normal agricultural practices, whenever they were needed. Data of the present study were statistically analyzed and the differences between the means of the treatments were considered significantly when they were more than the least significant differences (LSD) at the level of $5 \%$ using CoStat (Version 6.303, CoHort, USA, 1998-2004).

\section{RESULTS AND DISCUSSION}

\section{1- Grain and straw yields}

\section{1- Effect of mineral nitrogen fertilizer form}

The illustrated data in Table (3) demonstrated that nitrogen fertilization form had a high significant effect on grain and straw yields in both seasons, and it is also noticed that nitrogen fertilization in its slow release forms (UFCU and UCRPh) gave the highest values of grain and straw yields in both seasons compared to the fast soluble forms (Urea and AN), and this is dueto the gradual enrichment of available nitrogen to the plant in all its growth stages. These results are in great accordance with the same which obtained by (El-Aila, 1998 and El-Ghamry, 2003).

\section{2- Effect of mineral nitrogen fertilizer level}

As it was predicted, increasing nitrogen application levels increased grain and straw yield in both seasons, These results could be substantiated with those obtained by Zahran et al., (1997) and Sorour et al., (1998).

It is well known that nitrogen is the most important element for plant growth and development, and it is an integral component of many compounds essential for plant growth including chlorophyll and many enzymes(Mkhabela et al., 2001).

\section{3- Effect of organic amendments form}

Concerning the effect of organic amendments on grain and straw yields, it could be summarized that there was a high significant effect on grain and straw yields in both seasons, and this is because of the improvements in crop growth from direct and indirect effects. The direct effects from the improvements in nutrient and water content, and the indirect effects from a favorable rooting environment and possible weed suppression and a reduction in pests and diseases (FAO, 2005).

It is noticed that poultry manure is better than farmyard manure on improving wheat yield, and this is because of the high nutrients content in poultry manure as compared with farmyard manure, These results were matched with the results which obtained by Khaliq et al., (2004) 
Table (3): Single effect of nitrogen fertilization form, level and organic amendments treatments on grain and straw yield (g/pot) in both seasons.

\begin{tabular}{|c|c|c|c|c|}
\hline \multirow{2}{*}{ Treatments } & \multicolumn{2}{|c|}{ First season } & \multicolumn{2}{|c|}{ Second season } \\
\hline & Grain (g/pot) & Straw (g/pot) & Grain (g/pot) & Straw (g/pot) \\
\hline \multicolumn{5}{|c|}{ Mineral nitrogen fertilizer form } \\
\hline Urea & 16.10 & 18.86 & 15.84 & 18.56 \\
\hline AN & 14.96 & 17.30 & 14.51 & 17.66 \\
\hline UFCU & 18.46 & 22.87 & 19.20 & 22.31 \\
\hline UCRPh & 18.61 & 23.09 & 19.24 & 22.82 \\
\hline F-Test & ** & ** & ** & ** \\
\hline LSD at 0.05 & 0.58 & 1.27 & 0.46 & 0.51 \\
\hline \multicolumn{5}{|c|}{ Mineral nitrogen fertilizer level } \\
\hline $50 \mathrm{Kg} \mathrm{N} \mathrm{Fed}^{-1}$ & 15.90 & 19.19 & 15.94 & 18.95 \\
\hline $100 \mathrm{Kg} \mathrm{N} \mathrm{Fed}^{-1}$ & 18.17 & 21.87 & 18.45 & 21.72 \\
\hline F-Test & ** & ** & ** & $* *$ \\
\hline LSD at 0.05 & 0.44 & 0.46 & 0.26 & 0.51 \\
\hline \multicolumn{5}{|c|}{ Organic amendments form } \\
\hline Without & 13.36 & 16.04 & $12.42^{\mathrm{C}}$ & 16.03 \\
\hline FYM & 17.69 & 21.47 & $17.22^{\mathrm{b}}$ & 21.23 \\
\hline Chicken manure & 20.06 & 24.07 & $21.96^{a}$ & 23.75 \\
\hline F-Test & $\star *$ & ** & ** & $\star \star *$ \\
\hline LSD at 0.05 & 0.55 & 0.57 & 0.39 & 0.46 \\
\hline
\end{tabular}

\section{4- Effect of the interaction between treatments}

\subsection{1- Grain yield}

Concerning the interactions effect between treatments on grain yield in the first season which are shown in Tables (4 and 5), it could be concluded that there was a high significant effect of the interaction between mineral nitrogen fertilizer forms and levels, and UFRPh at $100 \mathrm{KgNFed}^{-1}$ which was the superior treatment. Also the interaction between mineral nitrogen fertilizer forms and organic amendments forms has a high significant effect on grain yield in the first season, and UFRPh with Ch.M was the superior treatment in increasing grain yield in the first season. The trend didn't change in the second season except the interaction between mineral nitrogen fertilizer levels and organic amendments forms which was high significant, and the Ch.M. form at $100 \mathrm{KgNFed}^{-1}$ which was the best treatment for enhancing the grain yield in the second season.

Table (4): Effect of interaction among nitrogen fertilization form, level and organic amendments treatments on grain yield ( $g / p o t)$ in the first season

\begin{tabular}{|c|c|c|c|c|c|c|}
\hline \multirow{2}{*}{ Treatments } & \multicolumn{3}{|c|}{$50 \mathrm{KgNFed}^{-1}$} & \multicolumn{3}{|c|}{$100 \mathrm{KgNFed}^{-1}$} \\
\hline & Without & FYM & Ch.M. & Without & FYM & Ch.M. \\
\hline Urea & 11.78 & 15.33 & 18.22 & 13.56 & 17.49 & 20.23 \\
\hline AN & 10.98 & 12.55 & 17.76 & 13.22 & 16.05 & 19.23 \\
\hline UFCU & 13.16 & 18.81 & 20.05 & 15.53 & 21.10 & 22.14 \\
\hline UCRPh & 13.15 & 18.98 & 20.03 & 15.49 & 21.18 & 22.79 \\
\hline Interactions & \multicolumn{2}{|l|}{$F X L$} & X Org & \multicolumn{2}{|c|}{ LXOrg } & F X L X Org \\
\hline F-Test & \multicolumn{2}{|l|}{ ** } & ** & \multicolumn{2}{|c|}{$\mathrm{ns}$} & ns \\
\hline LSD at 0.05 & \multicolumn{2}{|l|}{0.87} & 1.09 & \multicolumn{2}{|l|}{---- } & ---- \\
\hline
\end{tabular}


Table (5): Effect of interaction among nitrogen fertilization form, level and organic amendments treatments on grain yield $(\mathrm{g} / \mathrm{pot})$ in the second season

\begin{tabular}{|c|c|c|c|c|c|c|}
\hline \multirow{2}{*}{ Treatments } & \multicolumn{3}{|c|}{$50 \mathrm{KgNFed}^{-1}$} & \multicolumn{3}{|c|}{$100 \mathrm{KgNFed}^{-1}$} \\
\hline & Without & FYM & Ch.M. & Without & FYM & Ch.M. \\
\hline Urea & 11.08 & 15.46 & 17.27 & 13.16 & 18.29 & 19.75 \\
\hline AN & 10.75 & 14.00 & 16.43 & 11.93 & 14.78 & 19.19 \\
\hline UFCU & 11.65 & 17.92 & 23.72 & 14.39 & 19.64 & 27.86 \\
\hline UCRPh & 11.88 & 17.94 & 23.23 & 14.49 & 19.69 & 28.22 \\
\hline Interactions & \multicolumn{2}{|l|}{$\mathrm{FXL}$} & X Org & \multicolumn{2}{|c|}{ L X Org } & F X L X Org \\
\hline F-Test & \multicolumn{2}{|c|}{ ** } & ** & \multicolumn{2}{|c|}{ ** } & ns \\
\hline LSD at 0.05 & \multicolumn{2}{|l|}{0.52} & 0.79 & \multicolumn{2}{|l|}{0.56} & --- \\
\hline
\end{tabular}

\subsubsection{Straw yield}

Data in Tables (6 and 7) illustrated the effect of interaction between treatments on straw yield in both seasons.

In the first season, it could be summarized that there was a high significant effect of the interaction among nitrogen fertilization form and nitrogen fertilization level, and the mineral nitrogen of UFRPh at $100 \mathrm{KgNFed}$ 1 was the superior treatment, also the interaction between mineral nitrogen level and the organic amendments form affected straw yield and this effect was high significant. It is noticed that the high mineral nitrogen level with Ch.M. gave the highest straw yield in the first season. Finally, the interaction between the three treatments has a high significant effect on straw yield and the treatment of UFRPh at $100 \mathrm{KgNFed}^{-1}$ with Ch.M. was the best treatment in increasing straw yield in the first season.

All types of interaction among treatments affected highly significantly, straw yield in the second season, and the superior treatments were UCRPh at $100 \mathrm{KgNFed}^{-1}$, UFCU with Ch.M, $100 \mathrm{KgNFed}^{-1}$ with rock phosphate and UCRPh at $100 \mathrm{KgNFed}^{-1}$ with Ch.M as affected by the interactions among mineral nitrogen form with mineral nitrogen level, mineral nitrogen level with organic amendments form, mineral nitrogen level with organic amendments form and mineral nitrogen form with mineral nitrogen level and organic amendments form, respectively.

Table (6): Effect of interaction among nitrogen fertilization form, level and organic amendments treatments on straw yield (g/pot) in the first season

\begin{tabular}{|c|c|c|c|c|c|c|}
\hline \multirow{2}{*}{ Treatments } & \multicolumn{3}{|c|}{$50 \mathrm{KgNFed}^{-1}$} & \multicolumn{3}{|c|}{$100 \mathrm{KgNFed}^{-1}$} \\
\hline & Without & FYM & Ch.M. & Without & FYM & Ch.M. \\
\hline Urea & 14.35 & 19.07 & 21.76 & 15.39 & 20.24 & 22.34 \\
\hline AN & 12.62 & 16.40 & 20.42 & 13.68 & 19.31 & 21.37 \\
\hline UFCU & 17.16 & 20.50 & 25.85 & 18.62 & 27.21 & 27.84 \\
\hline UCRPh & 17.66 & 21.00 & 23.45 & 18.82 & 28.06 & 29.54 \\
\hline Interactions & \multicolumn{2}{|l|}{$\mathrm{FXL}$} & $\frac{1}{\mathrm{~F} \times \mathrm{Org}}$ & \multicolumn{2}{|c|}{ LXOrg } & F X L X Org \\
\hline F-Test & \multicolumn{2}{|l|}{$* *$} & Ns & \multicolumn{2}{|c|}{ ** } & ** \\
\hline LSD at 0.05 & \multicolumn{2}{|l|}{0.93} & ---- & \multicolumn{2}{|c|}{0.81} & 1.62 \\
\hline
\end{tabular}


Table (7): Effect of interaction among nitrogen fertilization form, level and organic amendments treatments on straw yield (g/pot) in the first season

\begin{tabular}{|c|c|c|c|c|c|c|}
\hline \multirow{2}{*}{ Treatments } & \multicolumn{3}{|c|}{$50 \mathrm{KgNFed}^{-1}$} & \multicolumn{3}{|c|}{$100 \mathrm{KgNFed}^{-1}$} \\
\hline & Without & FYM & Ch.M. & Without & FYM & Ch.M. \\
\hline Urea & 14.28 & 18.46 & 20.96 & 15.34 & 20.37 & 20.96 \\
\hline AN & 13.17 & 18.40 & 20.01 & 14.21 & 19.09 & 21.08 \\
\hline UFCU & 16.43 & 20.12 & 24.41 & 18.58 & 25.63 & 28.66 \\
\hline \begin{tabular}{|l|} 
UCRPh \\
\end{tabular} & 17.78 & 20.22 & 23.18 & 18.47 & 27.51 & 29.77 \\
\hline Interactions & \multicolumn{2}{|l|}{$\mathrm{FXL}$} & X Org & \multicolumn{2}{|c|}{ L X Org } & F X L X Org \\
\hline F-Test & \multirow{2}{*}{\multicolumn{2}{|c|}{$\begin{array}{c}* * \\
102\end{array}$}} & $* *$ & \multicolumn{2}{|c|}{ ** } & $\star *$ \\
\hline LSD at 0.05 & & 1.02 & 0.91 & \multicolumn{2}{|l|}{0.64} & 1.29 \\
\hline
\end{tabular}

\section{Nitrogen use efficiency}

Effect of mineral nitrogen fertilizer form on nitrogen use efficiency.

Nitrogen use efficiency is defined as the amount of harvested crop that is produced per unit of nitrogen supplied during the growing season (Fiez et al., 1994).

As shown in Fig. (1) nitrogen use efficiency differed according to the mineral nitrogen fertilizer form in the two nitrogen levels, and it is observed that the highest value of nitrogen use efficiency is attributed to the two slow $\mathrm{N}$ release sources and this is due to the gradual influx of available nitrogen to the plant in all its growth stages.

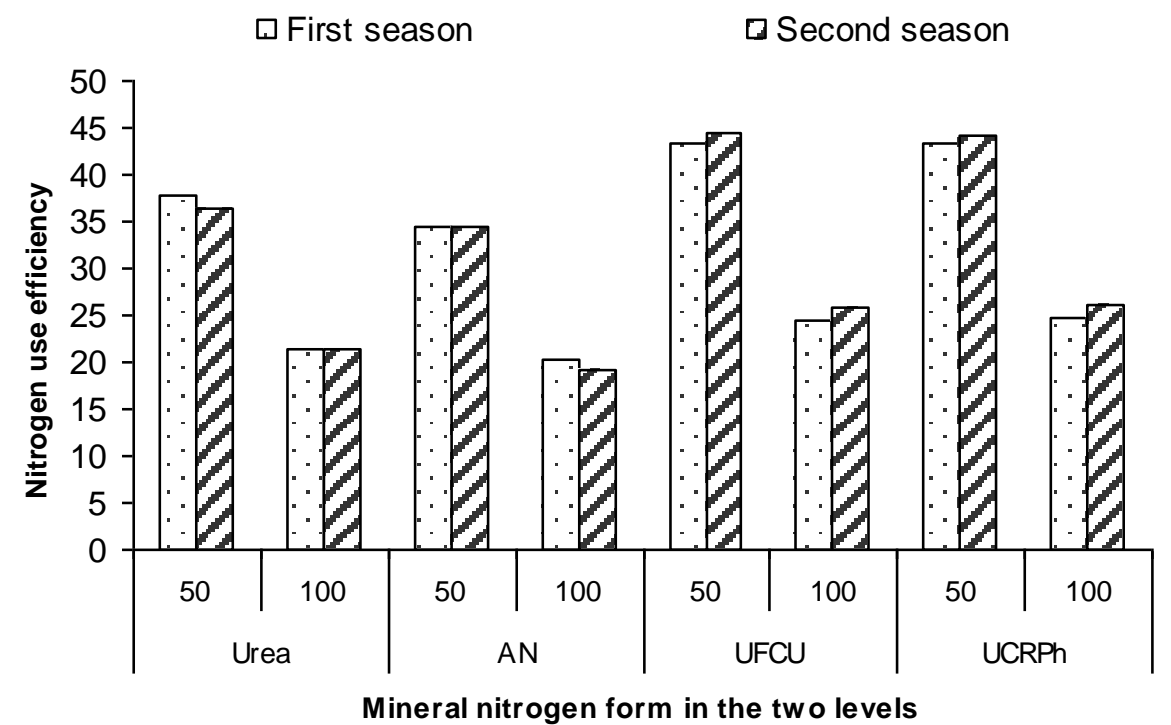

Figure (1): nitrogen use efficiency $(\mathrm{Kg} / \mathrm{N}$ Unit) as affected by mineral nitrogen fertilizer forms and levels

Effect of organic amendments form on nitrogen use efficiency.

As shown in Fig. (2) the organic nitrogen form interacted with the two levels of mineral nitrogen fertilization tend to increase nitrogen use efficiency 
in both seasons and the superior form was chicken manure, and this is due to its high nitrogen content

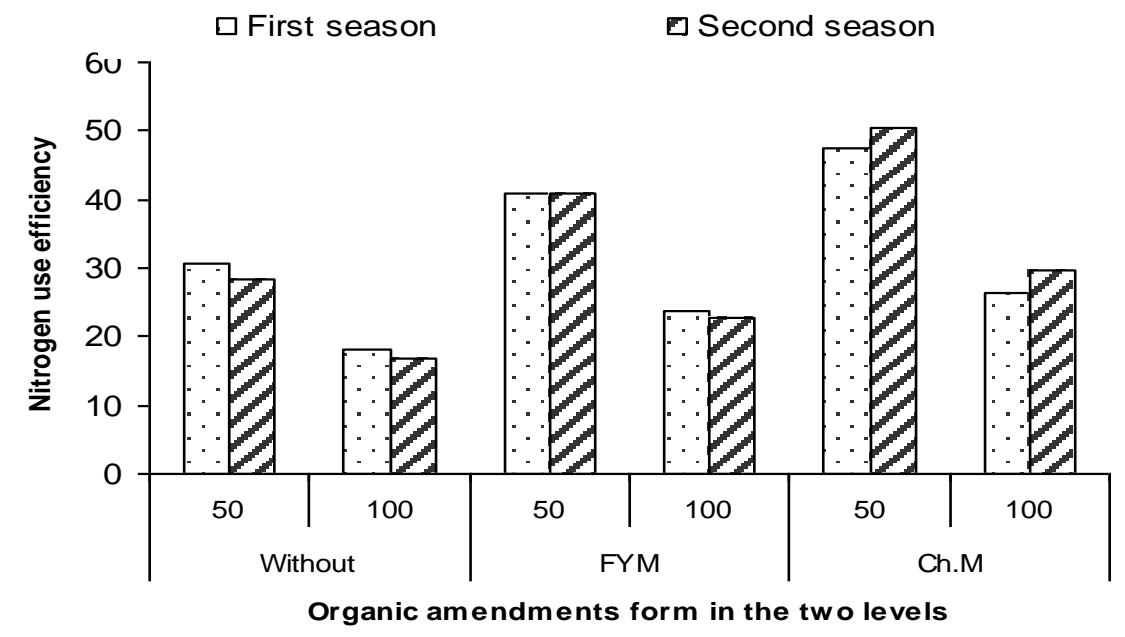

Figure (2): nitrogen use efficiency $(\mathrm{Kg} / \mathrm{N}$ Unit) as affected by the interaction btween used organic amendments forms and the two levels of $\mathbf{N}$ fertilizer

\section{REFERENCES}

Dewis, J. and F. Fertias (1970). Physical and Chemical Methods of Soil and Water Analysis. Soils Bulletin No. 10. FAO. Rome.

Duxbury, J.M., M.S. Smith \& J.W. Doran (1989). Soil organic matter as a source and sink of plant nutrients. In D.C. Coleman, J.M. Oades \& G. Uehara, eds. Dynamics of soil organic matter in tropical ecosystem, pp. 33-67. USA, University of Hawaii Press.

El-Aila, H. I. (1998). Studies on slow release nitrogenous fertilizers on the grass of sudan growth. J.Agric. Sci. Mansoura Univ. 23(6):2879-2886.

El-Ghamry, A.M. (2003). The use efficiency of slow release and soluble nitrogen fertilizers by corn (Zea maize L.) in alluvial soil. J. Agric. Sci. Mansoura Univ., Special Issue, Scientific symposium on "Problems of Soils and Waters in Dakahlia and Damietta Governorates" March $18,2003$.

Elizabeth AG. (2000). Preplant slow release nitrogen fertilizers produce similar bell pepper yields as split applications of soluble fertilizer. Agronomy Journal, 92, 388-393.

FAO (2005). "The Importance of Soil Organic Matter". Food and Agriculture Organization of the United Nations, Rome, 2005.

Fiez, T.E.; B.C. Miller and W.L. Pan (1994). Assessment of spatially variable nitrogen fertilizer management in winter wheat. J.Prod. Agric. 7:56-93.

Hesse, P. R. (1971)" A Text Book of Soil Chemical Analysis". Juan Murry (Publisher) Ltd, London.

Jackson, M. L. (1967). "Soil Chemical Analysis". Printice-Hall of India, New Delhi. 


\section{El-Hadidi, E.M. et al.}

Khaliq T.; T. Mahmoud ; J. Kamal and A. Masoud (2004). Effectiveness of farmyard manure, poultry manure and nitrogen for corn (Zea mays L.) productivity. International Journal of Agriculture and Biology, 2004 (Vol. 6) (No. 2) 260-263

Mkhabela M. S. ; M. S. Mkhabela and J. Pali-Shikhulu (2001). Response of maize (Zea moys L.) cultivars to different levels of nitrogen application in Swaziland. Seventh Eastern and Southern Africa Regional Maize Conf. pp.377-381.

Peterburgski, A. V. (1968)."Handbook of Agronomic Chemistry". Kolop Publishing House, Moscow, Russia.

Richards, L. A. (1954). "Diagnosis and Improving of Saline and Alkaline Soils". U. S., Salinity Laboratory Staff. Agric. Handbook, No.60.

Sorour, F. A., M.E. Mosalem and A.E. Khaffagy (1998). Effect of preceding crop, seeding rates and nitrogen levels on wheat growth and yield and its components. J. Agric. Res., Tanta Univ., 24 (3): 263281.

Sohar J. and U. Domoki (1980). Nitrite and nitrate in human nutrition. Bibliotheca Nutr. Deita 29;56-76.

Zahran, M. and M. E. Mosalem (1997). Effect of foliar application of some micronutrients under different levels of nitrogen on the productivity of wheat. J. Agric. Res., Tanta Univ., 19 (1): 5262.

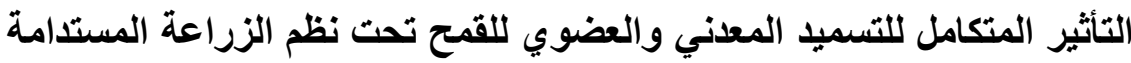

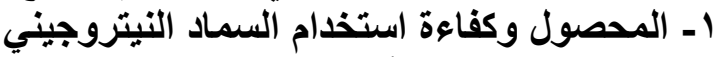

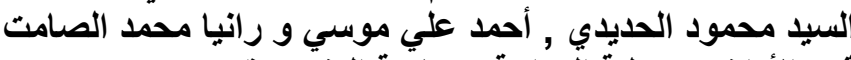

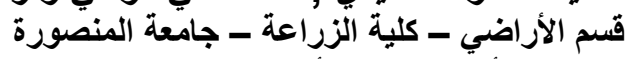

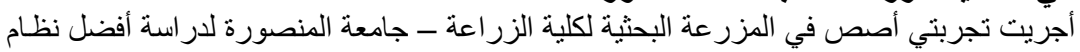

لللتسميد المعدني والعضوي و التي سوفت تؤدي إلي زيادة محصولي الحبوب و القنش بالإضافة إلي كفاءة استخدام

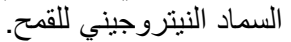

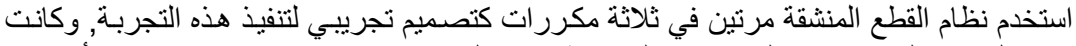

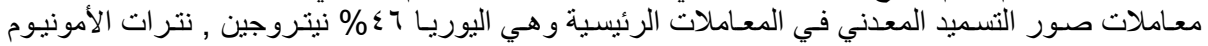

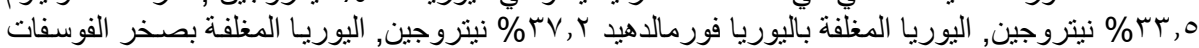

مثلت المعاملات المنثقة معدلات التسميد النيتروجيني المعدني وذلك بمعدلي .0 و . . 1 كجم

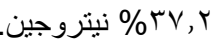

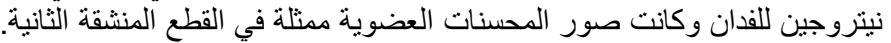

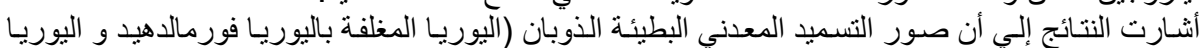

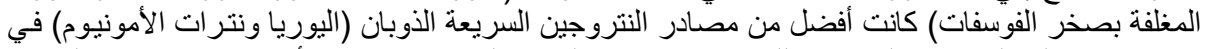

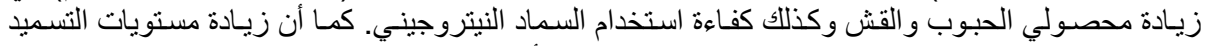

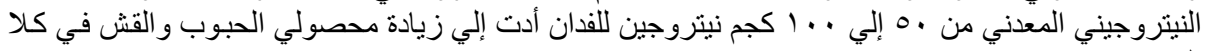

علي الجانب الأخر كان لصور الدحسنات العضوية تأثير كبير علي زيادة محصولي الحبوب و القش

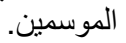

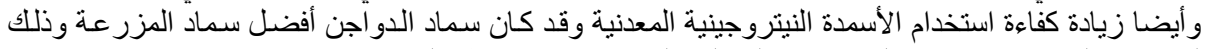

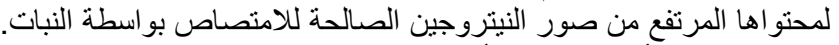

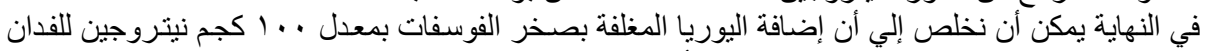

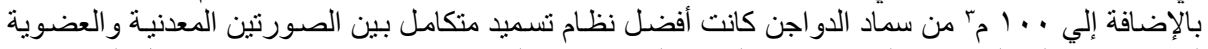

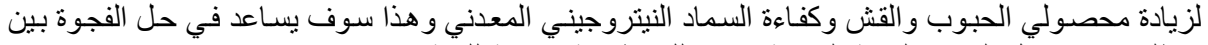
منظلبات محصول القمح و الكمية المنتجة منه وذلك بطريقة صديقة للبيئة. 